\title{
DWARF MISTLETOE AND BREEDING BIRD ABUNDANCE IN PONDEROSA PINE FORESTS
}

\author{
Thomas J. Parker ${ }^{1}$, Carol L. Chambers ${ }^{1,2}$, and Robert L. Mathiasen ${ }^{1}$
}

\begin{abstract}
AвstRact.-Southwestern dwarf mistletoe (Arceuthobium vaginatum subsp. cryptopodum) parasitizes ponderosa pine (Pinus ponderosa). It can kill severely infected trees and induce the growth of dense masses of branches that can affect foraging and nesting habitat for wildlife. We tested the hypothesis that higher densities of breeding birds would be correlated with higher levels of southwestern dwarf mistletoe in ponderosa pine forests of Arizona. We estimated densities of 15 species of breeding birds and measured 26 habitat elements in 19 stands. Average dwarf mistletoe ratings (DMR) ranged from 0.0 (uninfested) to 3.7 (severely infested). Although we observed higher densities with higher infestation of dwarf mistletoe for 2 bird species and lower densities for 3 bird species, the effect of dwarf mistletoe on these was minor. Instead, higher snag density, an indirect measure of past mistletoe infestation, was a more important predictor of bird density. With greater snag size or density, the species richness and densities of 3 bird species increased. Because dwarf mistletoe infection can create snags, retaining groups of dwarf mistletoe-infected trees in ponderosa pine stands will provide a continued source of snags, which are important habitat for many wildlife species.
\end{abstract}

Resumen.-El muérdago Arceuthobium vaginatum subsp. cryptopodum parasita árboles de pino ponderosa (Pinus ponderosa) y puede matar a los individuos severamente infectados e inducir densas masas de ramas capaces de afectar el hábitat de forrajeo y anidación de muchos animales silvestres. Pusimos a prueba la hipótesis de que detectaríamos una mayor densidad de aves en reproducción en bosques de pino ponderosa con niveles más altos de muérdago en Arizona. Estimamos la densidad de 15 especies de aves en reproducción y medimos 26 elementos del hábitat en 19 puntos. El promedio de muérdago (DMR) osciló entre 0.0 (sin infestar) y 3.7 (severamente infestados). Aunque con una mayor infestación de muérdago observamos densidades mayores o menores para dos y tres especies de aves respectivamente, el efecto del muérdago fue mínimo para estas especies. En cambio, una mayor densidad de tocones, una medida indirecta de infestaciones de muérdago pasadas, fue un predictor más importante de la densidad de aves. Con un aumento en el tamaño o la densidad de los tocones, aumentó la riqueza de especies de aves y la densidad de tres especies. Debido a que la invasión de muérdago puede crear tocones, retener grupos de árboles infectados con muérdago en áreas de pino ponderosa proporcionará una fuente continua de tocones, los cuales funcionan como hábitats importantes para muchas especies silvestres.

In the southwestern United States, southwestern dwarf mistletoe (Arceuthobium vaginatum subsp. cryptopodum; hereafter mistletoe) parasitizes and is the most widespread and economically damaging disease agent of southwestern ponderosa pine (Pinus ponderosa var. scopulorum; Hawksworth et al. 1989). Mistletoe induces the formation of profusely branched, dense masses of distorted host branches known as witches' brooms (or brooms; Tinnin et al. 1982, Hawksworth and Wiens 1996) that contribute to reduced growth and increased mortality in ponderosa pine (Hawksworth 1961), which can substantially affect forest structure (Mathiasen 1996). Stand-replacement fires are more likely in severely infested pine forests (Alexander and Hawksworth 1975, Koonce and Roth 1985,
Harrington and Hawksworth 1990, Parker et al. 2006, Stanton and Hadley 2010). Where timber production, fuels reduction, or forest restoration treatments are primary goals of forest management, managers attempt to control or remove mistletoe infestations (Hawksworth and Shaw 1988, Conklin and Fairweather 2010).

Mistletoe has a more dominant role in present-day forest ecology than it did prior to Euro-American settlement (Parmeter 1978). Fire suppression, livestock grazing, and silvicultural practices have dramatically increased tree densities through parts of the Southwest (Cooper 1960, Covington and Moore 1994, Saab et al. 1995, Mast et al. 1999, GrissinoMayer and Swetnam 2000). Mistletoe spreads more quickly in dense stands of evenly spaced

\footnotetext{
${ }^{1}$ Box 15018, School of Forestry, Northern Arizona University, Flagstaff, AZ 86011

2Corresponding author. E-mail: carol.chambers@nau.edu
} 
trees $\left(>175\right.$ trees $\left.\cdot \mathrm{ha}^{-1}\right)$ than in the open $\left(<120\right.$ trees $\left.\cdot \mathrm{ha}^{-1}\right)$, clumped stands that are believed to have dominated before 1870 (Hawksworth 1961). Prior to fire suppression, mistletoe was reduced by the more frequent fires characteristic of historic fire regimes (Alexander and Hawksworth 1975, Harrington and Hawksworth 1990, Hoffman et al. 2007). Consequently, mistletoe infestations are found over larger areas and at a greater intensity than in the past (Maffei and Beatty 1988, Conklin and Fairweather 2010). In addition, ponderosa pine stands with mistletoe have higher surface-fuel loads than noninfested stands (Harrington and Hawksworth 1990, Hoffman et al. 2007, Stanton and Hadley 2010, Klutsch et al. 2014). As part of fuels reduction and forest restoration programs in western states, many ponderosa pine forests are actively managed to decrease risk of catastrophic fire (i.e., the Healthy Forests Restoration Act of 2003), affording the opportunity to also manage mistletoe to enhance wildlife habitat in many southwestern ponderosa pine forests (Conklin and Fairweather 2010).

Mistletoe is a valuable resource for some bird species (Hawksworth and Wiens 1996, Ganey et al. 2013). Several species of songbirds nest in brooms (Bennetts 1991, Bennetts et al. 1996). Songbirds foraged for insects attracted to mistletoe shoots in Colorado (Hudler et al. 1979), and insect abundance and richness was greater in witches' brooms than non-broomed branches of Douglas-fir (Pseudotsuga menziesii) in Arizona (Smith et al. 2013). Birds may also be attracted to heterogeneous canopy structures induced by mistletoe infestation (Reich et al. 2000). Cavity-nesting birds nest in snags created by mistletoe infection, and in Colorado 24 of 28 bird species studied were more abundant in ponderosa pine stands that were severely infested by mistletoe (Bennetts et al. 1996).

Information is needed on wildlife use of mistletoe-infested stands to help resource managers design prescriptions that incorporate mistletoe as a habitat component. We hypothesized that the presence of mistletoe and brooms in ponderosa pine stands would be correlated with higher species richness and higher densities of individual bird species because of the increased number of foraging and roosting substrates provided by mistletoe. Our objective was to determine whether the severity of mistletoe infestation influenced the diurnal breeding bird community in northern Arizona after adjusting for all other influential habitat attributes.

\section{Methods \\ Study Sites}

We counted birds in ponderosa pine forests in northern Arizona in 1999 and 2000. The area was characterized by dry spring seasons, summer monsoons, and winter snow (Schubert 1974). Annual precipitation averaged $46.7 \mathrm{~cm}$ and $48.9 \mathrm{~cm}$, and temperatures averaged $6.8^{\circ} \mathrm{C}$ and $6.1{ }^{\circ} \mathrm{C}$ in 1999 and 2000 , respectively (NOAA 2006). We used 4 criteria to select stands: each needed to be (1) dominated by ponderosa pine ( $\geq 95 \%$ by basal area), (2) an adequate size for bird counts ( $\geq 32 \mathrm{ha}$ ), (3) spaced $\geq 1 \mathrm{~km}$ away from other stands, and (4) representative of a range of mistletoe infection in ponderosa pine forests on public lands in northern Arizona. To select stands with these criteria, we surveyed 63 stands using $\geq 20$ pointsamples in each (Avery and Burkhart 2002). At each point-sample we used a $4.7 \mathrm{~m}^{2} \cdot \mathrm{ha}^{-1}$ basal area factor prism and examined all "in" trees for mistletoe infection and recorded the tree species. Each "in" tree was assigned a dwarf mistletoe rating (DMR) using the 6-class system (Hawksworth 1977). This system divides the live crown of a tree into thirds and rates each third as $0=$ no infection, $1=$ less than half of the branches infected, or $2=$ more than half of the branches infected. The ratings for each third are then summed to yield a DMR for the tree. DMRs can range from 0 (uninfected) to as high as 6 (severely infected). Totaling the DMRs for all trees sampled in a stand, including uninfected trees, and dividing by the total number of trees examined provided a mean DMR for each stand. The mean DMR provided an estimate of the severity of mistletoe infection at the stand level (Hawksworth 1977, Parker and Mathiasen 2004).

Of the 63 stands we surveyed, we selected 19 that fit our criteria. Mean DMR, elevation, and slope ranged from 0.0 to $3.7,2218 \mathrm{~m}$ to $2545 \mathrm{~m}$, and $2^{\circ}$ to $14^{\circ}$, respectively. These stands were dominated by ponderosa pine $(99.2 \%$ by basal area); remaining species were Gambel oak (Quercus gambelii), New Mexican locust (Robinia neomexicana), southwestern white pine (Pinus strobiformis), Douglas-fir, junipers 
(Juniperus spp.) or pinyon pine (Pinus edulis). Basal area of stands ranged from 19.7 to 43.5 $\mathrm{m}^{2} \cdot \mathrm{ha}^{-1}$, tree density from 219 trees $\cdot \mathrm{ha}^{-1}$ to 964 trees $\cdot \mathrm{ha}^{-1}$, and quadratic mean diameter from $22 \mathrm{~cm}$ to $37 \mathrm{~cm}$. There was little $(<0.01 \%)$ understory shrub cover; dominant species were Fendler ceanothus (Ceanothus fendleri) and creeping barberry (Berberis repens). Cover of understory forbs and grasses ranged from $7.1 \%$ to $30.3 \%$ and included common mullein (Verbascum thapsus), white pussytoes (Antennaria parvifolia), mountain muhly (Muhlenbergia montana), columbine (Aquilegia spp.), silvery lupine (Lupinus argenteus), Arizona fescue (Festuca arizonica), pine dropseed (Blepharoneuron tricholepis), and blue grama (Bouteloua gracilis). Densities of snags $>12.7 \mathrm{~cm}$ diameter at breast height (dbh, $1.4 \mathrm{~m}$ above ground level) and $>1 \mathrm{~m}$ tall ranged from 1.8 to 70.4 per ha; $99.7 \%$ of snags were ponderosa pine. In stands with a mean $\mathrm{DMR} \geq 1.0,79 \%$ of ponderosa pine snags in decay class 1 and 2 (Raphael and White 1984) had evidence of past mistletoe infection (e.g., basal cups, distorted branches, dead brooms). For all stands, $56 \%$ of ponderosa pine snags in decay class 1 and 2 had evidence of past mistletoe infection.

The stands had a similar management history, and they had not been thinned or burned by prescribed fire or wildfire in the 5 years prior to our study. Fire suppression and livestock grazing occurred in the area since the 1800s, and wild ungulates (elk [Cervus canadensis] and mule deer [Odocoileus hemionus]) had access to all stands.

\section{Bird Surveys}

We established 8 point-count stations in each stand. One station originated at a random start location, and the remaining 7 stations were placed using a random compass bearing to establish direction and were $\geq 100 \mathrm{~m}$ from the stand boundary and $\geq 200 \mathrm{~m}$ apart. We surveyed birds using a modified version of a variable-radius point-count technique (Ralph et al. 1993), recording all birds detected by sight or by sound $\leq 100 \mathrm{~m}$ from the station. We estimated distance to the bird to the nearest meter using a handheld laser rangefinder (Haglöf Laser Pro 300XL, Haglöf Inc., Madison, MS). We surveyed stations 6 times per year between 22 May and 2 July in 1999 and 2000, with at least $6 \mathrm{~d}$ separating repeated surveys at a station. Sites were visited in random order within each survey period. We began counts $30 \mathrm{~min}$ after sunrise and completed them by 0830 . Two observers per year counted birds with one observer common to both years. To minimize bias, this observer also trained the other observer and observers rotated among all sites. After arriving at the station, we counted birds for 5 min after waiting a 1-min settling period (Szaro and Balda 1982, Ralph et al. 1993). We stopped counts when wind was $\geq 13 \mathrm{~km} \cdot \mathrm{h}^{-1}$ and when it was raining (Robbins et al. 1986).

We identified 15 bird species known or believed to be associated with mistletoe infestation that had large enough sample sizes for analyses. These species were categorized into 3 groups: birds that nested in foliage and thus could be affected by broom volume $(n=7$, Table 1), birds (primary and secondary cavity nesters and one flake nester) that nested in snags that might have resulted from mistletoe infection ( $n=7$, Table 1$)$, and one groundnesting bird that is affected by decreased stand density (i.e., greater understory development with lower overstory canopy; Griffis et al. 2001; Table 1). We estimated densities for those species with adequate sample sizes ( $\geq 60$ detections within a stand; Dark-eyed Junco, Mountain Chickadee, Yellow-rumped Warbler; for scientific names see Table 1) using Program DISTANCE (Buckland et al. 1993). For the 12 species without adequate detections, we tested whether the probability of detection between stands was similar by comparing detection distances for birds in the 5 most severely infested stands with those in the 5 least severely infested stands. Mean detection distances varied $<1 \mathrm{~m}$ between severely infested and uninfested stands $\left(F_{1,3232}\right.$ $=1.84, P=0.18)$. For this reason, and because average truncation distance in DISTANCE was $76.6 \mathrm{~m}$, detections beyond $75 \mathrm{~m}$ were removed from the data set and total counts were used as an index of avian abundance.

\section{Habitat Sampling}

Slope and aspect (precision to $1^{\circ}$ ) were measured at each of the 152 point-count stations. We sampled vegetation at five $11.3-\mathrm{m}$ radius plots (0.04 ha) at each point-count station with one sampling plot centered on the pointcount station and the 4 other plots placed $40 \mathrm{~m}$ from the point-count station. The first of these 


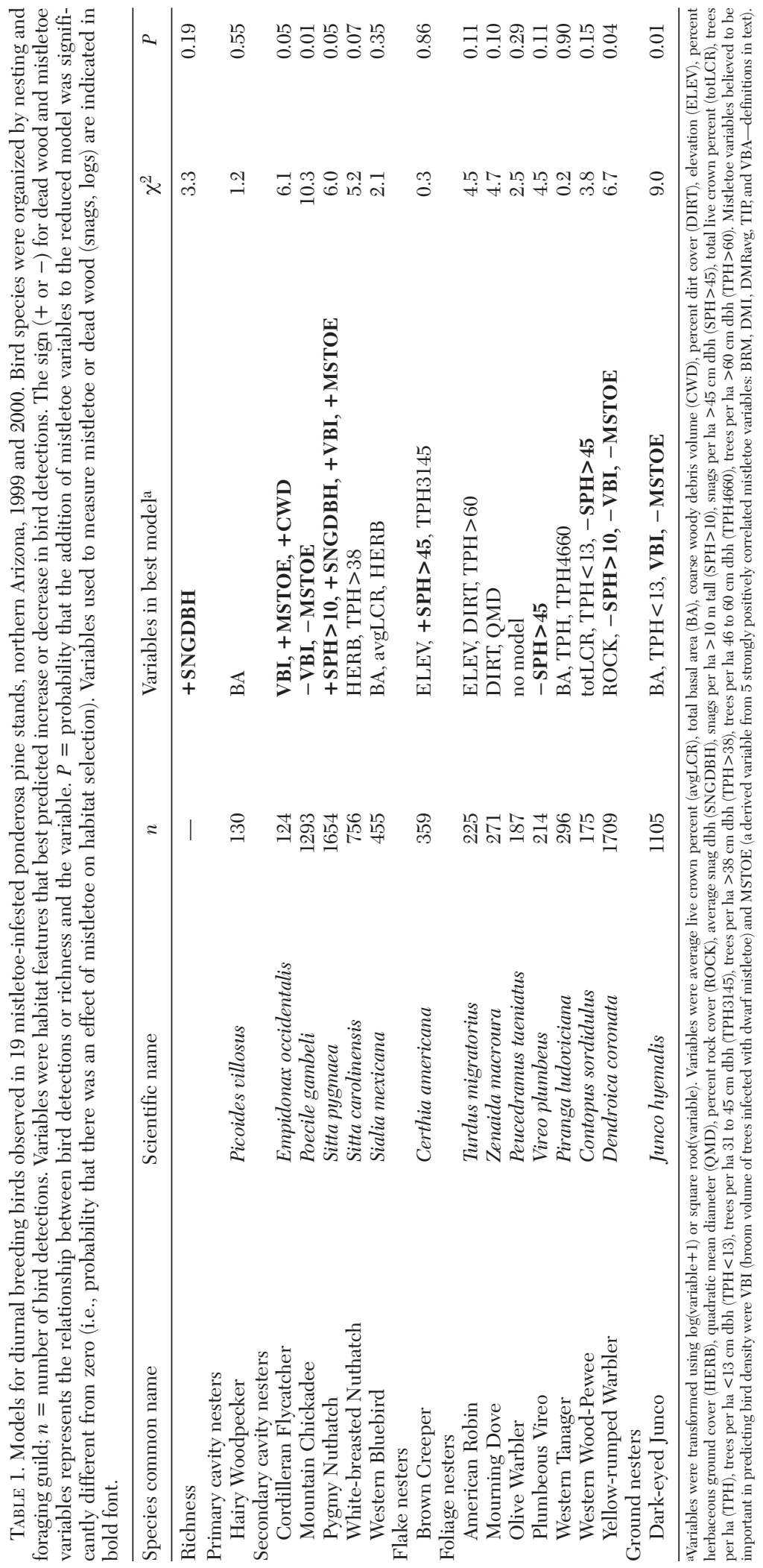


4 sampling plots was located at random and the other 3 points located at $90^{\circ}, 180^{\circ}$, and $270^{\circ}$ offsets from the randomly located plot.

Live trees and snags $\geq 12.7 \mathrm{~cm}$ dbh were measured in each of the five 11.3-m-radius plots established at each sample point. Tree species, dbh (measured to the nearest $\mathrm{cm}$ ), dwarf mistletoe rating (DMR, Hawksworth 1977), and tree height (estimated to the nearest $\mathrm{m}$ ) were recorded for each live tree. Percent live crown (percentage of the total height of the tree that had living branches) was visually estimated to the nearest $10 \%$ by the same person during both years of the study. The percentage of the live crown occupied by witches' brooms (broom volume) was visually estimated to the nearest $10 \%$ for each live tree in each of the 5 plots by the same person. The approximate volume occupied by brooms in the live crown of a tree was visually compressed and the approximate volume of the live crown occupied by brooms was then estimated.

Because measures of mistletoe were developed to quantify mistletoe infection rather than wildlife habitat, we derived 6 measures of mistletoe infection to characterize habitat: (1) Broom index (BRM), an index of broom volume, was calculated by multiplying the percent of live crown occupied by mistletoe brooms (the approximate volume of the live crown volume occupied by witches' brooms estimated to the nearest $10 \%$ ) by the percent live crown (the ratio of the length of the live crown to the total height of the tree estimated to the nearest $10 \%$ ) by the tree height, and then summing this value for all live trees in all plots established for each study site. Broom index was necessary to quantify broom development because severely infected trees do not always develop brooms, and broom development may depend partially on forest conditions such as basal area (Hawksworth 1961, Parker and Mathiasen 2004). Broom index can quantify the degree of broom development available for nesting and foraging more accurately than can other methods of quantifying broom development (e.g., broom volume rating or total broom volume), because it accounts for differential tree heights among forest stands (Parker and Mathiasen 2004). In general, the higher the broom index value for a study site, the greater the number of large trees with brooms in their crowns. (2) Average dwarf mistletoe rating for each stand
(DMRavg) was calculated by averaging the DMRs for all live trees (infected and uninfected) by species. (3) Average mistletoe rating of trees infected with dwarf mistletoe (DMI, an average that excluded uninfected trees), (4) percent of trees with mistletoe infection (TIP), and (5) broom volume estimated to the nearest $10 \%$ for all live trees (VBA) were also calculated, as well as (6) broom volume of live trees infected with dwarf mistletoe (VBI), which was similar to VBA except for excluding trees without mistletoe infection.

For each snag, we measured height, dbh, and decay class. We used 5 decay classes: (1) recently dead tree with needles, twigs, and limbs present; (2) needles absent, twigs and limbs present; (3) needles and twigs absent, limbs present and mostly intact; (4) limbs present but mostly broken; and (5) without limbs (after Raphael and White 1984). Evidence of mistletoe infection was noted only for class 1 and 2 snags (class 3, 4, and 5 snags no longer showed clear evidence of mistletoe infection due to bark degradation and related difficulty in identifying basal cups).

We measured woody plants $\geq 0.5 \mathrm{~m}$ tall and $<12.7 \mathrm{~cm}$ dbh on 5-m-radius plots within each 11.3-m-radius plot. We recorded species, height (to nearest $0.1 \mathrm{~m}$ ), and width in the widest direction (to nearest $0.1 \mathrm{~m}$ ) for each woody plant.

We used two 40-m transects at each pointcount station to measure canopy cover, ground cover, and downed woody debris. One transect was established on a random azimuth from the station, and another $180^{\circ}$ from the random azimuth. Presence or absence of canopy cover at 1-m intercepts was determined using a vertical sighting periscope (Rosenstock 1996). Ground cover was estimated on the same transects and at the same locations as canopy cover intercepts. We noted presence or absence of the following classes of ground cover: grasses, forbs, litter, shrubs, rock, and logs. In addition, we recorded diameter and length of logs with a diameter $\geq 12.7 \mathrm{~cm}$ at midpoint. We generated 34 vegetation and physiographic characteristics (e.g., basal area, trees per hectare by diameter class, elevation) for each study site to use in models of bird-habitat relationships.

\section{Data Analysis}

To test our hypothesis that the habitat and mistletoe variables (explanatory variables) were 
TABLE 2. Habitat variables evaluated as covariates predicting response of diurnal breeding birds and bird species richness to dwarf mistletoe infestation in ponderosa pine forests in northern Arizona, 1999-2000.

\begin{tabular}{|c|c|c|}
\hline Category & Variable & Definition \\
\hline Year & YEAR & Year the data were collected (1999 or 2000$)$ \\
\hline \multirow[t]{4}{*}{ Canopy } & $\mathrm{BA}$ & Total basal area $\left(\mathrm{m}^{2} \cdot \mathrm{ha}^{-1}\right)$ \\
\hline & CANOPY & Percent canopy cover \\
\hline & avgLCR & Average live crown percent \\
\hline & totLCR & Total live crown percent \\
\hline \multirow[t]{5}{*}{ Ground } & ELEV & Elevation $(\mathrm{m})$ \\
\hline & DIRT & Percent dirt cover \\
\hline & HERB & Percent herb cover \\
\hline & LITTER & Percent litter cover \\
\hline & ROCK & Percent rock cover \\
\hline \multirow[t]{5}{*}{ Dead wood } & CWD & Course woody debris volume $\left(\mathrm{m}^{3} \cdot \mathrm{ha}^{-1}\right)$ \\
\hline & SNGDBH & Average snag dbh $(\mathrm{cm})$ \\
\hline & $\mathrm{SPH}>10$ & Snags per ha $>10 \mathrm{~m}$ tall \\
\hline & $\mathrm{SPH}>1$ & Snags per ha $>1 \mathrm{~m}$ tall \\
\hline & $\mathrm{SPH}>45$ & Snags per ha $>45 \mathrm{~cm} \mathrm{dbh}$ \\
\hline \multirow[t]{3}{*}{ Small tree } & TPH & Trees per ha \\
\hline & $\mathrm{TPH}<13$ & Trees per ha $<13 \mathrm{~cm} \mathrm{dbh}$ \\
\hline & TPH1330 & Trees per ha 13 to $30 \mathrm{~cm} \mathrm{dbh}$ \\
\hline \multirow[t]{3}{*}{ Small tree } & TPH3145 & Trees per ha 31 to $45 \mathrm{~cm} \mathrm{dbh}$ \\
\hline & $\mathrm{TPH}>30$ & Trees per ha $>30 \mathrm{~cm} \mathrm{dbh}$ \\
\hline & $\mathrm{TPH}>38$ & Trees per ha $>38 \mathrm{~cm} \mathrm{dbh}$ \\
\hline \multirow[t]{4}{*}{ Large tree } & $\mathrm{TPH}>45$ & Trees per ha $>45 \mathrm{~cm} \mathrm{dbh}$ \\
\hline & TPH4660 & Trees per ha 46 to $60 \mathrm{~cm} \mathrm{dbh}$ \\
\hline & $\mathrm{TPH}>50$ & Trees per ha $>50 \mathrm{~cm} \mathrm{dbh}$ \\
\hline & $\mathrm{TPH}>60$ & Trees per ha $>60 \mathrm{~cm} \mathrm{dbh}$ \\
\hline \multirow{3}{*}{$\begin{array}{l}\text { Stand descriptor } \\
\text { variables for trees }\end{array}$} & DbhCOV & Coefficient of variation for $\mathrm{dbh}$ \\
\hline & HgtCOV & Coefficient of variation for tree height \\
\hline & QMD & Quadratic mean diameter $(\mathrm{cm})$ \\
\hline \multirow[t]{2}{*}{ Mistletoe } & MSTOE & $\begin{array}{l}\text { Variable for mistletoe derived from a combination } \\
\text { of BRM, DMI, DMRavg, TIP, and VBA }\end{array}$ \\
\hline & VBI & Broom volume of trees infected with dwarf mistletoe \\
\hline
\end{tabular}

aDefinitions in text.

related to bird counts or species richness, we analyzed stand-level averages of habitat characteristics, bird density estimates, and species richness (Zar 1999). We transformed variables using square root or $\log (\log [$ variable +1$])$ transformations to meet assumptions of normality. We used Pearson's correlation coefficient to illustrate direction and strength of the association between mistletoe and dead wood variables in models and estimates of bird densities and species richness (Neter et al. 1996). Because 5 measures of mistletoe infection (BRM, DMI, DMRavg, TIP, and VBA) were positively correlated $(r \geq 0.83, P<0.0001)$, we used a principal component analysis (PROC PRINCOMP; Khattree and Naik 2000) to reduce these measures to one synthetic variable (MSTOE) that explained $94 \%$ of the variation in the original data. For species that are primary or secondary cavity nesters, we also considered indirect measures of mistletoe infection (e.g., snags per ha $>1 \mathrm{~m}$ tall, snags per ha $>10 \mathrm{~m}$ tall, snags per ha $>45 \mathrm{~cm} \mathrm{dbh}$ ) as these variables were positively correlated with the mistletoe variable MSTOE $(r \geq 0.67$, $P<0.001)$.

To develop a model that included habitat variables that best predicted species richness or the density estimate for each bird species, we divided the habitat variables with the potential to influence density or richness into 6 groups (Table 2): canopy (e.g., total live crown, percent canopy cover), ground, dead wood, small-tree variables, large-tree variables, and stand-descriptor variables for trees. We then reduced the number of variables in each group to the subset that we considered to have explanatory power $(P \leq 0.15)$. Next, we created a model for each response variable that included all habitat variables identified in the first step, and retained those variables where $P \leq 0.05$. Therefore, this "reduced" model included all explanatory variables that explained variation in each response, except mistletoe variables. Finally, we added the 2 mistletoe variables (MSTOE and VBI) to each 
reduced model to create a "full" model and computed the difference in the amount of variation in the response explained by full and reduced models with a drop-in-deviance test (Ramsey and Schafer 2002). This provided a test of the effect of mistletoe on bird density after accounting for other important habitat variables. Because we sampled each stand for 2 years, we used year as a covariate in all models and all steps regardless of its explanatory power.

We used a repeated-measures, mixed-model approach for all analyses (PROC MIXED; Littell et al. 2006) to account for data collected from the same stand in both years, and used a first-order autoregressive covariance structure. We identified stands as a random effect and all other variables as fixed effects.

\section{RESULTS}

We observed 45 species during the 2-year study. We did not detect a relationship between bird species richness with mistletoe variables after adjusting for all other habitat variables (Table 1). Five of 15 bird species were positively $(n=2)$ or negatively $(n=3)$ associated with mistletoe. Two cavity-nesting species (Cordilleran Flycatcher and Pygmy Nuthatch) were more abundant with increased presence of mistletoe (Table 1). However, the relationships between these cavity nesters and mistletoe were weak relative to the influence of habitat elements, based on parameter estimates and their confidence intervals (Table 3). Although we detected fewer Yellow-rumped Warblers, Dark-eyed Juncos, and Mountain Chickadees with higher levels of mistletoe (Table 1), the negative influence of mistletoe in these models was also weak (Table 3).

Bird species richness was greater with increased numbers of larger-sized (dbh) snags $(P=0.02)$, and models for 3 of 7 cavity- and flake-nesting birds included some measure of snag density (Table 1, Table 3). Abundance of Pygmy Nuthatches was greater with higher numbers of larger-sized (dbh) snags $(P=0.01)$ and with higher density of snags $>10 \mathrm{~m}$ tall $(P=0.05)$ (Table 3). Abundance of Cordilleran Flycatchers was greater with increased amounts of coarse woody debris $(P=0.04)$ (Table 3$)$. Abundance of Brown Creepers was greater with increased numbers of snags $>45 \mathrm{~cm} \mathrm{dbh}$ $(P=0.02)$. We also noted relationships between 3 foliage-nesting birds and dead wood. Abundances of Plumbeous Vireo and Western Wood-Pewee decreased with higher numbers of snags $>45 \mathrm{~cm}$ dbh (Plumbeous Vireo: $P=0.02$; Western Wood-Pewee: $P=0.01$ ), and abundance of Yellow-rumped Warblers decreased with an increase in snags $>10 \mathrm{~m}$ tall $(P=0.79$; Tables 1, 3).

\section{Discussion}

Historically, ponderosa pine forests in the Southwest probably had lower levels of mistletoe than at present (Maffei and Beatty 1988, Conklin and Fairweather 2010), which may explain why we found little dependence of birds on mistletoe in our study. Although Bennetts et al. (1996) reported significant $(P<0.05)$ positive associations between mistletoe, bird species richness, and 4 bird species (Hairy Woodpecker, Western Wood-Pewee, Steller's Jay [Cyanocitta stelleri], and Violet-green Swallow [Tachycineta thalassina]), we found none of these relationships. Parks et al. (1999) and Garnett et al. (2006) documented use of brooms by several mammal species, including squirrels (Sciurus spp.). The presence of squirrels may deter broom use by birds since squirrels can be nest predators (e.g., Saab and Vierling 2001, Ibarzabal and Desrochers 2004).

However, mistletoe may still represent an important resource for birds. We found nests of Mourning Dove and Yellow-rumped Warbler in brooms (Parker 2001). Many birds in northern Arizona are permanent residents or short-distance migrants, so brooms may provide roosting or foraging substrates during the colder winter months.

The 2 bird species in our study with positive, albeit weak, mistletoe associations were cavity nesters (Cordilleran Flycatcher and Pygmy Nuthatch) that were also positively associated with measures of coarse woody debris, snag density, or snag size. Bennetts et al. (1996) found a positive correlation between mistletoe levels and snag numbers, and they speculated that mistletoe led to snag creation in the stands they studied. Given the strong correlation we found between severity of mistletoe infection and snag density, mistletoe could be an important factor in recruiting snags as wildlife habitat for some species. However, other cavity-nesting birds in our study showed no or a negative association 
TABLE 3. Fixed effects $(\beta)$ and lower (LCI) and upper (UCI) confidence interval limits for models predicting habitat relationships (CWD, SNGDBH, SPH $>10$, ROCK, BA, TPH $<13$; variables defined in text) where effects of dwarf mistletoe (VBI, MSTOE) were significant (see Table 1) on breeding birds in ponderosa pine forest, northern Arizona, 1999-2000.

\begin{tabular}{|c|c|c|c|}
\hline Species & $\beta$ & LCI & UCI \\
\hline \multicolumn{4}{|c|}{ Positive response to dwarf mistletoe } \\
\hline \multicolumn{4}{|c|}{ Cordilleran Flycatcher } \\
\hline Intercept & -2.2999 & -6.2172 & 1.6173 \\
\hline Year 1999 & -0.1 & -0.4304 & 0.2304 \\
\hline Year 2000 & 0 & - & - \\
\hline CWD & 0.8371 & 0.06483 & 1.6093 \\
\hline VBI & -0.05416 & -0.1856 & 0.07725 \\
\hline MSTOE & 0.03168 & -0.1732 & 0.2365 \\
\hline \multicolumn{4}{|c|}{ Pygmy Nuthatch } \\
\hline Intercept & -104.93 & -215.29 & 5.4346 \\
\hline Year 1999 & -38.1053 & -45.4236 & -30.787 \\
\hline Year 2000 & 0 & - & - \\
\hline SNGDBH & 107.03 & 34.6329 & 179.43 \\
\hline $\mathrm{SPH}>10$ & 19.633 & 0.2602 & 39.0058 \\
\hline VBI & 0.7204 & -2.0931 & 3.5339 \\
\hline MSTOE & -1.5167 & -7.1548 & 4.1214 \\
\hline \multicolumn{4}{|c|}{ Negative response to dwarf mistletoe } \\
\hline \multicolumn{4}{|c|}{ Mountain Chickadee } \\
\hline Intercept & 0.9829 & 0.7097 & 1.256 \\
\hline Year 1999 & -0.02105 & -0.2399 & 0.1978 \\
\hline Year 2000 & 0 & - & - \\
\hline VBI & 0.006324 & -0.04323 & 0.05588 \\
\hline MSTOE & -0.02825 & -0.0981 & 0.0416 \\
\hline \multicolumn{4}{|c|}{ Yellow-rumped Warbler } \\
\hline Intercept & 1.3067 & 0.767 & 1.8464 \\
\hline Year 1999 & -0.4105 & -0.5719 & -0.2491 \\
\hline Year 2000 & 0 & - & - \\
\hline ROCK & -0.03275 & -0.06799 & 0.002486 \\
\hline $\mathrm{SPH}>10$ & -0.04705 & -0.4244 & 0.3303 \\
\hline VBI & 0.03295 & -0.02688 & 0.09277 \\
\hline MSTOE & -0.09469 & -0.2144 & 0.02501 \\
\hline \multicolumn{4}{|c|}{ Dark-eyed Junco } \\
\hline Intercept & 2.7022 & 1.3309 & 4.0735 \\
\hline Year 1999 & 0.2895 & -0.00454 & 0.5835 \\
\hline Year 2000 & 0 & - & - \\
\hline $\mathrm{BA}$ & -0.03219 & -0.05692 & -0.00745 \\
\hline $\mathrm{TPH}<13$ & -0.4664 & -0.8871 & -0.04565 \\
\hline VBI & 0.02272 & -0.03034 & 0.07578 \\
\hline MSTOE & -0.04503 & -0.1216 & 0.03159 \\
\hline
\end{tabular}

with ponderosa pine snags and down wood. White-breasted Nuthatches, Mountain Chickadees, and Western Bluebirds did not appear to be dependent on presence of ponderosa pine snags, possibly because they can nest in excavated and natural cavities of dead or live trees (Balda 1975, Cunningham et al. 1980).

The dependence of several cavity nesters on snags indicates the importance of maintaining this habitat element across the landscape to provide nesting sites, and mistletoe appears to be an important contributor to snag formation. Recommendations for snag densities in ponderosa pine have varied from 4.2 to 7.4 per hectare (United States Forest Service 1996, Ganey 2016). Because ponderosa pine snags remain standing only a short time (i.e., up to $90 \%$ of ponderosa pine snags fall $\leq 10$ years after creation; Ganey et al. 2015) and because mistletoe kills trees in a very slow manner (Hawksworth and Geils 1990), mistletoe infestation can be a long-term source of snags. Therefore, we recommend retaining groups of mistletoe-infected ponderosa pines to help create snags on a continuing basis because they create important habitat for many wildlife species.

As forests become more severely infested with a parasite such as mistletoe, the structure and composition of the plant community may shift; for example, dominant trees may die and less susceptible tree and shrub species may 
then derive a competitive advantage and become more common (Press and Phoenix 2005). As plant species diversity increases, avian diversity may also increase (MacArthur and MacArthur 1961, Rotenberry 1985). In our study, although overstory canopy cover decreased with increasing mistletoe infestation (MSTOE, $r=-0.52, P=0.0008$ ), herbaceous cover did not increase $(r=-0.21, P=0.2)$. Our sites represented simple plant communities; they were primarily ponderosa pine with little understory. Although snags were more common in severely infested stands, snag formation did not significantly affect the understory plant community.

We tried 6 measures of mistletoe to explain habitat associations. Although the relationships we found between bird density and dwarf mistletoe were weak, the variables we used (MSTOE and VBI) were useful in explaining habitat relationships for some birds. Because 5 were highly correlated (combined as MSTOE), any of these measures of dwarf mistletoe infection can be used. Resource managers can use the measures that are the easiest to take in the field or the most accepted in practice (e.g., DMR) as a tool to assess mistletoe's effect on breeding birds in the Southwest.

\section{ACKNOWLEDGMENTS}

We thank J. McCabe, C. Weston, H. Herlyn, G. Garnett, and O. Harper for assistance in the field. Thanks to A. Brown of the Peaks Ranger District, Coconino National Forest, for help in locating stands. R.J. Steidl assisted in data analysis, and W.M. Block, S.S. Rosenstock, R.J. Steidl, and 2 anonymous reviewers provided helpful comments on earlier versions of the manuscript. This study was funded by the U.S. Forest Service Rocky Mountain Research Station, Flagstaff, Arizona, and by McIntire-Stennis appropriations to Northern Arizona University.

\section{Literature Cited}

Alexander, M.E., and F.G. Hawksworth. 1975. Wildland fires and dwarf mistletoes: a literature review of ecology and prescribed burning. U.S. Forest Service General Technical Report RM-14, Rocky Mountain Forest and Range Experiment Station, Fort Collins, $\mathrm{CO}$

Avery, T.E., AND H.E. Burkhart. 2002. Forest measurements. McGraw-Hill, New York, NY.
BALDA, R.P. 1975. The relationship of secondary cavity nesters to snag densities in western coniferous forests. U.S. Forest Service Wildlife Habitat Technical Bulletin \#1, Southwest Region, Albuquerque, NM.

BennetTs, R.E. 1991. The influence of dwarf mistletoe infestation on bird communities in Colorado ponderosa pine forests. Master's thesis, Colorado State University, Fort Collins, CO.

Bennetts, R.E., G.C. White, F.G. Hawkworth, and S.E. SEvers. 1996. The influence of dwarf mistletoe on bird communities in Colorado ponderosa pine forests. Ecological Applications 6:899-909.

Buckland, S.T., D.R. ANDERSON, K.P. Burnham, and J.L. LACKE. 1993. Distance sampling: estimating abundance of biological populations. Chapman and Hall, New York, NY.

Conklin, D.A., and M.L. Fairweather. 2010. Dwarf mistletoes and their management in the Southwest. R3-FH-10-01, USDA Forest Service, Southwestern Region, Albuquerque, NM.

Cooper, C.F. 1960. Changes in vegetation, structure, and growth of southwestern pine forests since white settlement. Ecological Monographs 30:129-164.

Covington, W.W., and M.M. Moore. 1994. Postsettlement changes in natural fire regimes and forest structure: ecological restoration of old-growth ponderosa pine forest. Pages 153-181 in R.N. Sampson, and D.L. Adams, editors, Assessing forest ecosystem health in the Inland West. The Haworth Press, Binghamton, NY.

Cunningham, J.B., R.P. Balda, and W.S. Gaud. 1980. Selection and use of snags by secondary cavitynesting birds of the ponderosa pine forest. Research Paper RM-222, USDA Forest Service, Rocky Mountain Forest and Range Experiment Station, Fort Collins, CO.

GANEY, J.L. 2016. Recommendations for snag retention in southwestern mixed-conifer and ponderosa pine forests: history and current status. Wildlife Society Bulletin 40:192-201.

Ganey, J.L., D.L. Apprill, T.A. Rawlinson, S.C. Kyle, R.S. JONNES, AND J.P. WARD JR. 2013. Nesting habitat of Mexican Spotted Owls in the Sacramento Mountains, New Mexico. Journal of Wildlife Management 77:1426-1435.

Ganey, J.L., G.C. White, J.S. Jenness, and S.C. Vojta. 2015. Mark-recapture estimation of snag standing rates in northern Arizona mixed-conifer and ponderosa pine forests. Journal of Wildlife Management 79:1369-1377.

Garnett, G.N., C.L. Chambers, and R.L. Mathiasen. 2006. Use of witches' brooms by Abert squirrels in ponderosa pine forests. Wildlife Society Bulletin 34:467-472.

Griffis, K.L., J.A. Crawford, M.R. Wagner, and W.H. MOIR. 2001. Understory response to management treatments in northern Arizona ponderosa pine forests. Forest Ecology and Management 146:239-245.

Grissino-MaYer, H.D., AND T.W. Swetnam. 2000. Century-scale climate forcing of fire regimes in the American Southwest. Holocene 10:213-220.

Harrington, M.G., and F.G. Hawksworth. 1990. Interactions of fire and dwarf mistletoe on mortality of Southwestern ponderosa pine. Pages 234-240 in S.J. Krammes, editor, Proceedings of the Symposium on Effects of Fire Management of Southwestern Natural Resources, Tucson, Arizona. General Technical 
Report RM-191, USDA Forest Service, Rocky Mountain Forest and Range Experiment Station, Fort Collins, CO.

Hawksworth, F.G. 1961. Dwarf mistletoe of ponderosa pine in the Southwest. Technical Bulletin No. 1246, USDA Forest Service, Washington, DC.

Hawksworth, F.G. 1977. The 6-class dwarf mistletoe rating system. General Technical Report RM-48, U.S. Forest Service, Rocky Mountain Forest and Range Experiment Station, Fort Collins, CO.

Hawksworth, F.G., AND B.W. GeILs. 1990. How long do mistletoe-infected ponderosa pines live? Western Journal of Applied Forestry 5:47-48.

Hawksworth, F.G., and G.C. Shaw. 1988. Damage and control of major diseases of ponderosa pine. Pages 99-108 in D.M. Baumgartner and J.E. Lotan, editors, Ponderosa pine, the species and its management: symposium proceedings. Washington State University Cooperative Extension, Pullman, WA.

Hawksworth, F.G., G.C. Shaw, and B. TKacz. 1989. Damage and control of diseases of Southwest ponderosa pine. Pages 116-129 in A. Tecle, W.W. Covington, and R.H. Hamre, technical coordinators, Proceedings of a conference on multiresource management of ponderosa pine forests. General Technical Report RM185, USDA Forest Service, Rocky Mountain Forest and Range Experiment Station, Fort Collins, CO.

Hawksworth, F.G., and D. Wiens. 1996. Dwarf mistletoes: biology, pathology, and systematics. U.S. Forest Service Agriculture Handbook 709, Washington, DC.

Hoffman, C.M., R.L. Mathiasen, and C.H. Sieg. 2007. Dwarf mistletoe effects on fuel loadings in ponderosa pine forests in northern Arizona. Canadian Journal of Forest Research 37:662-670.

Hudler, G.W., N. Oshima, and F.G. Hawksworth. 1979. Bird dissemination of dwarf mistletoe on ponderosa pine in Colorado. American Midland Naturalist 102:273-280.

Ibarzabal, J., And A. Desrochers. 2004. A nest predator's view of a managed forest: Gray Jay (Perisoreus canadensis) movement patterns in response to forest edges. Auk 121:162-169.

KhattreE, R., AND D.N. NAIK. 2000. Multivariate data reduction and discrimination with SAS software. SAS Institute, Cary, NC.

Klutsch, J.G., R.D. Beam, W.R. Jacobi, and J.F. Negron. 2014. Bark beetles and dwarf mistletoe interact to alter downed woody material, canopy structure, and stand characteristics in northern Colorado ponderosa pine. Forest Ecology and Management 315: 63-71.

KoOnce, A.L., AND L.F. Roth. 1985. The effects of dwarf mistletoe on fuel in precommercial ponderosa pine stands. Pages $66-72$ in L.R. Donoghue and R.E. Martin, editors, Weather-the drive train connecting the solar engine to forest ecosystems. Proceedings of the 8th Conference on Fire and Forest Meteorology. Society of American Foresters, Bethesda, MD.

Littell, R., G. Milliken, W. Stroup, R. Wolfinger, AND O. Schabenberger. 2006. SAS for mixed models. 2nd edition. SAS Press, Cary, NC.

MacArthur, R.H., and J.W. MacArThur. 1961. On bird species diversity. Ecology 42:594-598.

MAFFEI, H., AND J. BEATTY. 1988. Changes in the incidence of dwarf mistletoe over 30 years in the Southwest. Pages 88-90 in B.J. VanDerKamp, editor, Proceedings of the 36th Annual Western International Forest
Disease Work Conference. Department of Forest Sciences, University of British Columbia, Vancouver, British Columbia, Canada.

Mast, J.N., P.Z. Fulé, M.M. Moore, W.W. Covington, and A.E.M. WaLtz. 1999. Restoration of presettlement age structure of an Arizona ponderosa pine forest. Ecological Applications 9:228-239.

Mathiasen, R.L. 1996. Dwarf mistletoes in forest canopies. Northwest Science 70:61-70.

[NOAA] National Oceanic and Atmospheric AdminisTRATION. 2006. NOAA Satellite and Information Service. [Accessed 16 Mar 2006]. http://www.ncdc .noaa.gov/oa/ncdc.html

Neter, J., M.H. Kutner, C.J. Nachtsheim, and W. Wasserman. 1996. Applied linear statistical models. 4th edition. McGraw-Hill, Inc., Boston, MA.

ParkeR, T.J. 2001. Bird communities in dwarf mistletoe infested ponderosa pine forests. Master's thesis, Northern Arizona University, Flagstaff, AZ.

Parker, T.J., K.M. Clancy, and R.L. Mathiasen. 2006. Interactions among fire, insects and pathogens in coniferous forests of the interior western United States and Canada. Agricultural and Forest Entomology 8:167-189.

Parker, T.J., and R.L. Mathiasen. 2004. A comparison of rating systems for dwarf mistletoe-induced witches' brooms in ponderosa pine. Western Journal of Applied Forestry 19:54-59.

Parks, C.G., E.L. Bull, R.O. Tinnin, J.F. Shepherd, and A.K. Blumton. 1999. Wildlife use of dwarf mistletoe brooms in Douglas-fir in northeast Oregon. Western Journal of Applied Forestry 14:100-105.

Parmeter, J.R., JR. 1978. Forest stand dynamics and ecological factors in relation to dwarf mistletoe spread, impact, and control. Pages 16-30 in R.F. Scharpf and J.R. Parmeter, editors, Proceedings of the Symposium on Dwarf Mistletoe Control through Forest Management. General Technical Report PSW-31, USDA Forest Service, Pacific Southwest Forest and Range Experiment Station, Berkeley, CA.

Press, M.C., AND G.K. Phoenix. 2005. Impacts of parasitic plants on natural communities. New Phytologist 166:737-751.

Ralph, J.C., G.R. Geupel, P. Pyle, T.E. Martin, and D.F. DESANTE. 1993. Handbook of field methods for monitoring landbirds. General Technical Report PSW-GTR-144, USDA Forest Service, Pacific Southwest Research Station, Berkeley, CA.

Ramsey, F.L., AND D.W. Schafer. 2002. The statistical sleuth. 2nd edition. Duxbury Press, Belmont, CA.

Raphael, M.G., and M. White. 1984. Use of snags by cavity-nesting birds in the Sierra Nevada. Wildlife Monographs 86:1-66.

Reich, R.M., J. Lundquist, and V.A. Bravo. 2000. Spatial relationship of resident and migratory birds and canopy openings in diseased ponderosa pine forests. Environmental Modeling and Software 15: 189-197.

Robbins, C.S., D. Bystrak, and P.H. Geissler. 1986. The Breeding Bird Survey: its first fifteen years, 1965-1979. U.S. Fish and Wildlife Service Resource Publication 157, Washington, DC.

Rosenstock, S.S. 1996. Habitat relationships of breeding birds in northern Arizona ponderosa pine and pine-oak forests. Final Report. Technical Report Number 23, Arizona Game and Fish Department, Phoenix, AZ 
RotenberRy, J.T. 1985. The role of habitat in avian community composition: physiognomy or floristics? Oecologia 67:213-217.

SAAB, V.A., C.E. Bock, T.D. Rich, and D.S. Dobkin. 1995 Livestock grazing effects in western North America. Pages 311-356 in T.E. Martin and D.M. Finch, editors, Ecology and management of neotropical migratory birds. Oxford University Press, New York, NY.

SAAB, V.A., AND K.T. VierLing. 2001. Reproductive success of Lewis's Woodpecker in burned pine and cottonwood riparian forests. Condor 103:491-501.

Schubert, G.H. 1974. Silviculture of southwestern ponderosa pine: the status of our knowledge. Research Paper RM-123, USDA Forest Service, Rocky Mountain Forest and Range Experiment Station, Fort Collins, CO.

Smith, L., R. Hofstetter, and R. Mathiasen. 2013. Insect communities associated with Douglas-fir dwarf mistletoe witches' brooms in northern Arizona. Southwestern Naturalist 58:395-402.

Stanton, S., and K.S. Hadley. 2010. Influence of western dwarf mistletoe (Arceuthobium campylopodum Engelm.) on surface fuels and snag abundance in mature ponderosa pine and mixed conifer stands in central Oregon. Natural Areas Journal 30:261-270.

SZARO, R.C., AND R.P. BALDA. 1982. Selection and monitoring of avian indicator species: an example from a ponderosa pine forest in the southwest. General Technical Report RM-89, USDA Forest Service, Rocky Mountain Forest and Range Experiment Station, Fort Collins, CO.

Tinnin, R.O., F.G. Hawksworth, and D.M. KnUtson. 1982. Witches' broom formation in conifers infected by Arceuthobium spp.: an example of parasitic impact upon community dynamics. American Midland Naturalist 107:351-359.

United States Forest Service. 1996. Record of decision for amendment of forest plans: Arizona and New Mexico. USDA Forest Service Southwestern Region, Albuquerque, NM.

ZAR, J.H. 1999. Biostatistical analysis. 4th edition. Prentice Hall, Inc., Upper Saddle River, NJ.

Received 6 May 2016 Accepted 9 November 2016

Published online 15 March 2017 